\title{
The Role of Strategic Talent Management (STM) to Enhance Jobs Performances in Oil \& Gas Companies in the UAE: A Conceptual Framework
}

\author{
Ibraheem Hasan Thani Al Hammadi, Safiah Sidek, Samer Ali Al-shami
}

\begin{abstract}
Workforce related issues have sustained to fuel the war for talent in Oil \& Gas sector, in which the UAE is one of the main players in this industry globally. Most of the local companies are heavily depending on the knowledge and skills of foreign experts for its competitive advantage. In this case, jobs roles localization (Emiratization) has become an imperative and efforts need to be done to lure the local workforce to be part of the local companies. Therefore, there is a need to propose a Strategic Talent Management (STM) so that the local employees can contribute productively to the economic growth of the country. This study aims to address the issues of the shortage of the skilled domestic workforce by proposing a STM practices to enhance job performance among local employees for achieving the competitive advantage of the Oil \& Gas companies in the $U A E$. As the initial stage of the investigation, this paper presents the conceptual framework, highlighting the constructs of the variables to be investigated in this study. Drawn from the analysis of the existing literature, this study is framed by four concepts, which are the STM, job motivation, job retention and job performance. Positioned within a positivist paradigm, eight hypotheses have been formulated in the study. It is expected that the development of the conceptual framework of this study will guide the investigation of the role of strategic talent management that can enhance the job performance of the local employees in the oil and gas companies at the UAE.
\end{abstract}

Keywords - strategic talent management, job motivation, job retention, job performance, conceptual framework

\section{INTRODUCTION}

\subsection{Human resource in oil and gas industry}

In the United Arab Emirates (UAE), Oil \& Gas commerce is the most prominent source of the economic evolution where active participation of local workforce contributes positively to both financial growth as well as the productivity of the nation. Since a while, the UAE and the other five Arab Gulf States have made concerted efforts to make the transition into less oil-dependent, and more diversified economies, with varying levels of success (Ewers 2016).With the world's seventh largest proven crude oil reserves, the UAE is a responsible producer and critical partner in global energy markets (Embassy of The United

Revised Manuscript Received on April 12, 2019.

Ibraheem Hasan Thani Al Hammadi, P. O. Box 3827, Abu Dhabi, United Arab Emirates (UAE). (E-mail:p061810009@utem.edu.my)

Safiah Sidek,Institut Pengurusan Teknologi dan Keusahawanan, Pusat Bahasa dan Pembangunan Insan, Universiti Teknikal Malaysia Melaka, C-ACT. (E-mail: safiahsidek@utem.edu.my)

Samer Ali Al-shami, Institut Pengurusan Teknologi dan Keusahawanan, Pusat Bahasa dan Pembangunan Insan, Universiti Teknikal Malaysia Melaka, C-ACT
Arab Emirated 2019).As a mainstay to the economy, oil exports now account for about 25 percent of the UAE's gross domestic product.Abu Dhabi holds 94 percent of the U.A.E.'s oil reserves, or about 90 billion barrels (2017) which can be found both offshore and onshore (The International Trade Administration 2018).

Nevertheless, the existence of foreign labourers in large numbers in the UAE has many social, political and cultural implications as well as implications on demographics which exceeded all reasonable boundaries when it reached up to 80 percent of the UAE population (Alzaabi 2012).Due to these factors, the UAE is characterised by a heavy dependency on foreign labour and some levels of national unemployment. Besides; Oil \& Gas and gas industry in UAE has been facing high employee turnover rate (Harhara, Singh, and Hussain 2015). As oil industry has such a significant role in UAE economy (Alzaabi 2012), the assessment of the impact of the nationalization policy on human capital development is a significant consideration.

According to J. Pegram et al., (Pegram et al. 2018), in the oil \& gas industry job role localization becoming an imperative, however, to nationlize job role, it gives big challenges to the industry.S. Hannawi and I. Al Salmi (Hannawi and Salmi 2014) mentioned, UAE faced by morale problems and skill imbalance in the human resource area.Moreover, the oil \& gas industry in UAE has been facing a high employee turnover rate (Harhara, Singh, and Hussain 2015; Shamsi et al. 2015). This alters the issues of domestic skill workforce shortage and which require focusing on STM of UAE nationals' competencies in Oil \& Gas industry. A. H. Alkhalaf et al., (Alkhalaf, Zaballero, and Alzahmi 2015) suggested for Oil \& Gas organizations to implement a STM utilizing a competency-based approach as an option to close skills gaps within the organisation.

\subsection{Strategic talent management in organisation}

The shortage of highly skilled and motivated talent in an organization gives big challenges to human resource management globally. The speciality of employees gives the leads for organizations to sustain their marketplace; hence their competitive advantage. Due to that, the development of human capital in organizations should be systematically managed to ensure that employees are developed very well 
in order to contribute positively to their job performance. To develop a competitive advantage organization, it is important that organizations truly leverage the workforce as a competitive weapon (Cappelli and Keller 2014; Marimuthu.M, Arokiasamy.L, Ismail 2009).Accordingly; it is very logical that company's strategy determines the competencies that employees should have to help and support successful development. However; there have been very limited works that specifically dealt with the analysis of the relationship between the strategic human resource management on the different competencies developed by individuals in their work (Díaz-Fernández, López-Cabrales, and Valle-Cabrera 2014).

To develop a competitive advantage in organizations, many researchers argue that strategic talent management (STM) is a mechanism to help organizations achieve objectives.This is why many organizations and managers are seeking to develop a talent management strategy (Naulleau 2018).The talent mind-set has helped organizations in recruiting the best talents (Rutledge et al. 2016; Sharma and Bhatnagar 2009).However; talent competencies proved very difficult to incorporate across the institution without significant administrative support and commitment to longterm sustainability (Rutledge et al. 2016).Human capital management can be used to promote the majority of employees' talents through attraction, development, deployment, and retention practices (M. Christina Meyers, van Woerkom, and Dries 2013).In fact, talent management includes a complete set of processes in order to identify, employ and manage individuals to implement business strategy successfully (Tafti, Mahmoudsalehi, and Amiri 2017).

Nevertheless; there is a lack of study in the area of human capital competency (Tripathi and Agrawal 2014). A study by M. T. Beamond et al., (Beamond, Farndale, and Härtel 2016) identified generic talents management issues such as difficulties in replicating local tacit knowledge and skill shortages.Currently, the study stressed a lack of effective talent management strategies and particularly empirical research (Beamond, Farndale, and Härtel 2016; GallardoGallardo and Thunnissen 2016; Skuza, Scullion, and McDonnell 2013; Thunnissen 2016).Furthermore; research on STM has not kept pace with the research on multinational companies (MNCs) (Ahammad et al. 2018).Likewise, it is crucial to understand, analyze and strengthen STM practices in the organizations for sustainable competitive advantage (Schuler and Tarique 2012).

Thus, this papers aims to present a conceptual framework to investigate the role of a strategic management to enhance the job performance of the local employees in oil and gas companies in the UAE. Drawn from the analysis of the existing literature, a conceptual framework consisting of four constructs, namely the strategic talent management, job retention, job motivation and job performance has been developed. The presentation of this paper is organised into four sections. After the introduction section, the second section presents methodology for the conduct of the literature review. This is followed by the third section that presents the literature review, highlighting on the evidence for the selection of the four variables. The fourth section discusses the construction of the conceptual framework and the relevant hypotheses that will be tested. The last section concludes this paper with comments for the limitations and future works.

\section{RESEARCH METHOD}

To propose a conceptualise STM, the study reviewed the journal articles published between 2014 - 2018. First, the search terms were defined. The keywords used in the search process were 'talent management' and 'human capital'. Second, various academic databases were utilised to identify the journal articles including Scopus and Google Scholar. Third, several criteria were determined and used to filter the articles. With respect to the criteria, abstract of articles were examined to check if they cover one or more of the talent management topics. Fourth, the reference lists of the shortlisted articles were also carefully evaluated to ensure that there were no other articles of relevance which were omitted in the research. Finally, the content of each article was thoroughly reviewed to ensure that the articles fit into the context of talent management. This study has found 170 articles in the field of talent management, however only 23 articles related to the study.

According to the review, the most STM practices is often linked with career development (Alias, Noor, and Hassan 2014; Awan and Farhan 2016; Khilji, Tarique, and Schuler 2015; Lacey and Groves 2014; Pobst 2014; Rabbi 2015; Vnoučková 2016) and mentorship and coaching (Corner 2014; Foster, Ooms, and Marks-Maran 2015; James, Rayner, and Bruno 2015; Lacey and Groves 2014; Pobst 2014; Subramaniam et al. 2015; Vnoučková 2016).Meanwhile, STM also linked to talent attraction and selection (Awan and Farhan 2016; R. Lyria, Namusonge, and Karanja 2017; Maria Christina Meyers and van Woerkom 2014; Rabbi 2015), talent acquisition (Khilji, Tarique, and Schuler 2015; Montgomery and Oladapo 2014; Rudhumbu and Maphosa 2017; Sahay 2014; Wu and Issa 2014; Zhang et al. 2015) and, talent recruitment (Cooke, Saini, and Wang 2014; Cui, Khan, and Tarba 2016; Dutta 2014; Pobst 2014).Figure 1 show the STM dimension was cited by authors since the year 2014 - 2018. While, table 1 shows the attributes of dimensions of STM founds from literature reading.

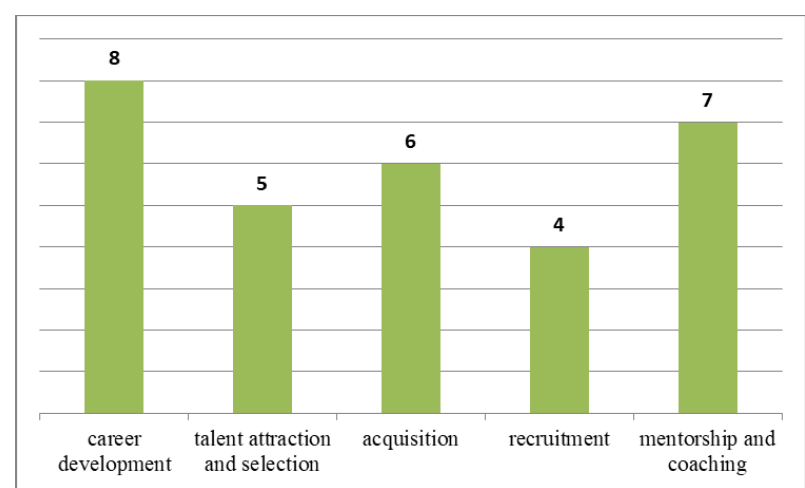

Figure 1: Strategic Talent Management Cited by Authors

Published By Blue Eyes Intelligence Engineering \& Sciences Publication 
Table 1: Dimensions of Strategic Talent Management

\begin{tabular}{|c|c|c|}
\hline No. & $\begin{array}{c}\text { Talent } \\
\text { management } \\
\text { practices }\end{array}$ & Author(s) \\
\hline 1. & $\begin{array}{l}\text { Career } \\
\text { development }\end{array}$ & $\begin{array}{l}\text { (Alias, Noor, and Hassan 2014; } \\
\text { Awan and Farhan 2016; Khilji, } \\
\text { Tarique, and Schuler 2015; Lacey } \\
\text { and Groves 2014; Pobst 2014; } \\
\text { Rabbi 2015; Vnoučková 2016) }\end{array}$ \\
\hline 2. & $\begin{array}{l}\text { Talent } \\
\text { attraction and } \\
\text { selection }\end{array}$ & $\begin{array}{l}\text { (Awan and Farhan 2016; R. Lyria, } \\
\text { Namusonge, and Karanja 2017; } \\
\text { Maria Christina Meyers and van } \\
\text { Woerkom 2014; Rabbi 2015) }\end{array}$ \\
\hline 3. & Acquisition & $\begin{array}{l}\text { (Khilji, Tarique, and Schuler 2015; } \\
\text { Montgomery and Oladapo 2014; } \\
\text { Rudhumbu and Maphosa 2017; } \\
\text { Sahay 2014; Wu and Issa 2014; } \\
\text { Zhang et al. 2015) }\end{array}$ \\
\hline 4. & Recruitment & $\begin{array}{l}\text { (Cooke, Saini, and Wang 2014; } \\
\text { Cui, Khan, and Tarba 2016; Dutta } \\
\text { 2014; Pobst 2014)(Rashid, } \\
\text { Alzahrani, and Al-shami. S 2018) }\end{array}$ \\
\hline 5. & $\begin{array}{l}\text { Mentorship and } \\
\text { coaching }\end{array}$ & $\begin{array}{l}\text { (Corner 2014; Foster, Ooms, and } \\
\text { Marks-Maran 2015; James, } \\
\text { Rayner, and Bruno 2015; Lacey } \\
\text { and Groves 2014; Pobst 2014; } \\
\text { Subramaniam et al. 2015; } \\
\text { Vnoučková 2016) }\end{array}$ \\
\hline
\end{tabular}

\section{RESULTS AND DISCUSSION}

\subsection{Conceptualisation of Strategic Talent Management Practices}

Talent management practice within organization is an international human resource strategy that seeks to identify, develop, deploy and retain talented and high potential employees (Dixit and Arrawatia 2018; Mangusho, Murei, and Nelima 2015).There is little doubt that the area of talent management has become one of fastest growing areas of academic work in the management field over recent decades (Collings, Scullion, and Vaiman 2015; Gelens et al. 2014; Vnoučková 2016) while in contrary the strategic importance of talent management research shows it increasing at a slow rate (Kontoghiorghes 2015).Moreover, many articles on talent management are rather descriptive in nature, mostly attempting to define what talent management is, or distinguish it from traditional human resource management practice (Thunnissen, Boselie, and Fruytier 2013).Additionally, many leaders attach great value to talent and talent management, but there are still little known about how and how well talent management really works in practice (Thunnissen 2016).

Among the 170 reviewed journal articles, 23 articles discussed talent management practices as presented in table 1. Eight of these articles simply identified the career development (Alias, Noor, and Hassan 2014; Awan and Farhan 2016; Khilji, Tarique, and Schuler 2015; Lacey and Groves 2014; Pobst 2014; Rabbi 2015; Vnoučková 2016); five articles discussed talent attraction and selection (Awan and Farhan 2016; R. Lyria, Namusonge, and Karanja 2017; Maria Christina Meyers and van Woerkom 2014; Rabbi
2015); six article discussed talent acquisition (Khilji, Tarique, and Schuler 2015; Montgomery and Oladapo 2014; Rudhumbu and Maphosa 2017; Sahay 2014; Wu and Issa 2014; Zhang et al. 2015); four articles discussed talent recruitment (Cooke, Saini, and Wang 2014; Cui, Khan, and Tarba 2016; Dutta 2014; Pobst 2014); and seven articles discussed mentorship and coaching (Corner 2014; Foster, Ooms, and Marks-Maran 2015; James, Rayner, and Bruno 2015; Lacey and Groves 2014; Pobst 2014; Subramaniam et al. 2015; Vnoučková 2016) as a talent management practice in the organisation.

\subsection{Strategic Talent Management and job Performance}

STM is required to bridge the gap (Schreuder and Noorman 2019).It is emerged as a result of the efficient recruitment based system (Schreuder and Noorman 2019; Ugwu and Osisioma 2017). According to sub-section 3.1, the study identifies STM practices from past study of talent management.These practices will measure the extent of job performance when the entities apply the practice.It is a core functional unit of an organization to enhance performance (Dixit and Arrawatia 2018).Study by J. Mwanzi et al., (Mwanzi, Wamitu, and Kiama 2017) found that, talent management program was important in organisational growth because of its effectiveness in daily operations in order to determine right talents.Furthermore; a study by $\mathrm{M}$. Mahjoub et al., (Mahjoub et al. 2018) shows the same result of above literature indicates that STM makes company succession and STM practice on recruitment, training and development are directly linked with the job performance in oil sector (Alaraqi 2017). The learning by S. A. N. Tabatabaei and M. Mami (Tabatabaei and Mami 2015) indicated that talent management is the main core of human resource management and the main factor of organizations success where STM are related to job performance.Therefore the study formulate below hypothesis:

\section{H1: STM has significant positive relationship with job performance}

\subsection{Strategic Talent Management and Job Motivation}

Job motivation can be powerful vehicle for learning and development, for maintaining and enhancing employees' physical and mental health, and for achieving control and flexibility simultaneously (Ashraf 2017; Parker 2014). A study by P. Kumari \& P. Bahuguna (Kumari and Bahuguna 2012) and R. Gopal \& R. Chowdhury (Gopal and Chowdhury 2014) founds STM practices significantly contribute to job motivation in oil \& gas industry in India.Furthermore; these practices have direct impact on employee motivation in the service industry (Hitu and Baroda 2016). Another study by $\mathbf{M}$. Vinodkumar and $\mathbf{M}$. Bhasi (Vinodkumar and Bhasi 2010) found out employers who facilitate with good environment of work such as management safety is also contributing to the job motivation of the employees. S. Antonsen et al., (Antonsen, Skarholt, and Ringstad 2012) argue, if low motivation among employees, it can affect the safety negatively in the oil \& 
gas industry.J. Mwanzi et al., (Mwanzi, Wamitu, and Kiama 2017) recommend, company should enhance job motivation towards employees by enhancing talent management programs and therefore; can contribute to organizational growth.Meanwhile, F. Froese (Froese 2012) found out, the workers are motivated for expatriate by international experience and job environment.A case study by S. Shortland (Shortland 2018) found out, women workers are motivated to the STM more than men as they easily accept to have expats assigned for their career development in oil \& gas industry where STM are related to job motivation. As a result; the study formulates hypothesis as below:

\section{H2: STM has significant positive relationship with job motivation}

\subsection{Strategic Talent Management and Job Retention}

Employee turnover is a problem faced in international human resource management at this time.Moreover; the knowledge transfer issue due to the aging workforce and talent crisis is more acute in developed countries as compared to developing countries especially in upstream sector which is suffering the most (Sumbal et al. 2018).As an employer, the STM plays crucial factor in order to ensure employee retain in the company.A. Harhara et al., (Harhara, Singh, and Hussain 2015) stated, organisational environment contributes as a main factor for ensuring employee retention.Furthermore, qualities of training and recruitment strategies increase employee's retention and reducing turnover of employees (Deery and Jago 2015; Smith, Oczkowski, and Smith 2011).Meanwhile, N. Jefri and N. Daud (Jefri and Daud 2016) propose STM practice in order to retain employees in oil \& gas company in Malaysia via work environment, work-life balance, career development along with compensation and benefits.As well a study by J. Mwanzi et al., (Mwanzi, Wamitu, and Kiama 2017) shows that, talent management programs promote high retention rate of employees in the companies.According to C. Osaro (Osaro 2016), STM practice of talent attraction is significantly contributing to job retention of employees and career growth in oil firms.N. Dhanpat et al., (Dhanpat et al. 2019) also found, STM practice (training and development) was the stronger factor for job security that contributed to job retention among workers.Meanwhile, STM practices as a whole were positively related to employee's retention in Oil \& Gas company (Fathaniy 2011). Hence, the study argues that STM are related to job retention which formulates hypothesis as below:

\section{H3: STM has significant positive relationship with job retention}

\subsection{Job Motivation and Job Retention}

A study by Y. Mangusho et al., (Mangusho, Murei, and Nelima 2015) found out, competitive salary packages and rewards give motivation to employees to retain in the organisations. Furthermore, M. Sarmad et al., (Sarmad et al. 2016) founds, practical handling of compensation in company motivates employees in order to retain.M.
Ahammad et al., (Ahammad et al. 2012) and F. Adzei \& R. Atinga (Adzei and Atinga 2012) found out, a financial benefit is a motivational factor that drives the employees to retain in their companies.A study by A. Osibanjo et al., (Osibanjo et al. 2014) founds financial benefits such as compensation packages given by employer provide motivation to employees and contribute to job retention in the company.C. Rirchardson and H. Wong (Richardson and Wong 2018) found, poor motivation which is disappointment with work has contributed to reducing retention plans among workers.Henceforward, the study argues that job motivation are related to job retention that formulates below hypothesis:

\section{H4: Job motivation has significant positive relationship with job retention}

\subsection{Job Motivation and Job performance}

Success of organizations is dependent on motivated employees.A study by O. Robescu and A. Iancu (Robescu and Iancu 2016) found, that a large part of employees agree that recognition motivates them and affect performance of the company.Moreover, employees feel highly motivated through talent management practices such as healthy and cooperative work environment rather than salary in order to improve job performance (Hitu and Baroda 2016). On the other hand, financial benefits motivate workers to accomplish and drive better job performance (Dias et al. 2017; Osibanjo et al. 2014; Pang and Lu 2018).Yet; reduction of job motivation contributes to poorer performance (Bartlomiejczuk and Jin 2015). Hence, the study argues that job motivation are related to job performance which formulates below hypothesis:

\section{H5: Job motivation has significant positive relationship with job performance}

\subsection{Job Retention and Job performance}

Talentretention aimstotakemeasurestoencourage employees to remain in theirorganization for maximum period of time (R. K. Lyria, Namusonge, and Karanja 2014).Retaining talented employees is a predicament often faced in fast developing countries due to the highly competitive nature of their business environment (Idris 2012).Oil \& Gas industry business leaders who fail to implement adequate talent retention strategies are experiencing reduced profits and sustainability challenges (Nwoye 2017).Job retention is a field of talent management to ensure organizations achieve their objectives.A study by D. Gberevbie (Gberevbie 2010) found out, it is more profitable for organizations to put in place appropriate employee-retention strategies such as good organization's image, staff participation in decision making, enhancing regular salary packages and humane treatment of employees as strategies for job performance.Meanwhile; another study by M. Chiboiwa et al., (Chiboiwa, Samuel, and Chipunza 2010) found out, poor in managerial system administration such as reward system turn the employees either to quit the job or not contributing to their organizational goals.Hence, the study argues that job retention are related to job performance which 
formulates hypothesis as below:

\section{H6: Job retention has significant positive relationship with job performance}

\subsection{Strategic Talent Management, Job Motivation and Job performance}

A study by M. Mahjoub et al., (Mahjoub et al. 2018) found that, job motivation mediated relationship between STM and organization performance whereby the result shows that the succession of the projects has been implemented in the industry. G. Ashraf (Ashraf 2017) derived literature of STM and the study conceptualised talent management can give positive impact to the organization performance and mediated by job motivation of employee in the company.Meanwhile, a study by $\mathbf{M}$. Vinodkumar and M. Bhasi (Vinodkumar and Bhasi 2010) found out, job motivation of the workers contributed as a mediator factor between safety management practice and safety performance of the organisation. Therefore; the study formulates the hypothesis as below:

\section{H7: The association between STM and the job performance is mediated by job motivation}

\subsection{Strategic Talent Management, Job Retention and Job performance}

In competitive market place, talent retention is a primary driver for organisational success. Study by A. Ali et al., (Ali, Zumrah, and Samah 2017) found an empirical evidence of mediating roles of job retention to STM and organizational citizenship behaviour.Furthermore, F. Aldamoe et al., (Aldamoe, Yazam, and Ahmid 2011) concluded from literature, job retention is likely to mediate in the relationship between STM and job performance. Therefore; the study formulates the hypothesis as below:

\section{H8: The association between STM and the job performance is mediated by job retention}

\subsection{Conceptual Framework}

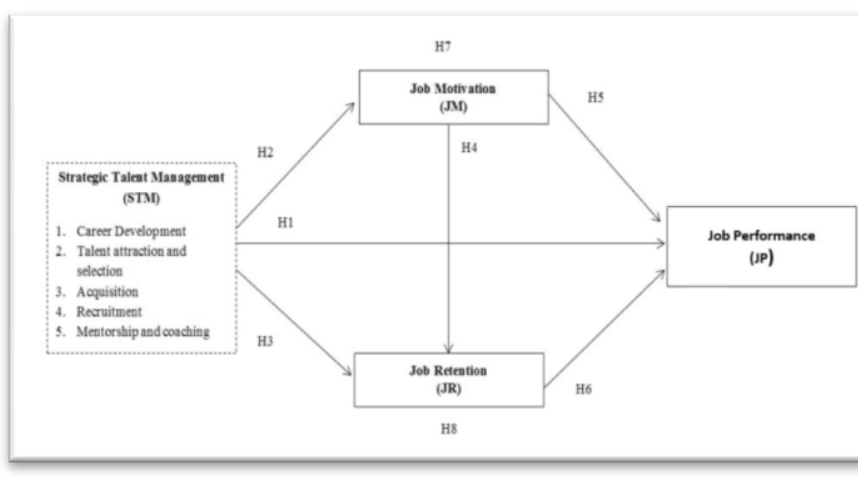

\section{CONCLUSIONS}

With the world's seventh largest proven crude oil reserves, the UAE is a responsible producer and an essential partner in global energy markets.Nevertheless; the UAE is categorized by a heavy dependency on foreign labour in Oil \& Gas industry with high employee turnover rate which resulted in managing this industry particularly in the area of human resources and talent management with challenges.Moreover; according to the statement of problem, there is real lack of study as STM practices has not been widely researched empirically to present the real impact if expats in critical positions leave the country.Therefore, this study is conceptualised the framework to measuring the level of implementation STM practices in the industry.

This study will contribute to the existing knowledge on talent management by examining how the concept of talent will be understood through STM. What talent management practice is in place? What talent management challenges might be confronting Oil \& Gas companies in UAE through the view of non-HR managers? The most important part of this study is arguing about the existence of correlations between talent management and organizations performance.The link between talent management and organization performance has been proven as it significantly contributes to the existing theoretical and practical gaps (Lepak \& Shaw, 2008; Tarique \& Schuler, 2010; BethkeLangenegger et al., 2011; Holden \& Vaiman, 2013).The positive relationships between well-developed talent management and company performance confirm the relevance of talent management implementation (Latukha, 2014).

Thus, case study research is recommended to validate the conceptual framework in the oil \& gas industry. This will also allow for testing the research hypotheses as formulated.

\section{ACKNOWLEDGEMENT}

The authors would like to express their gratitude to the Universiti Teknikal Malaysia Melaka for the assistance and support in this publication.

\section{REFERENCES}

1. Adzei, Francis A., and Roger A. Atinga. 2012. "Motivation and Retention of Health Workers in Ghana's District Hospitals." Journal of Health Organization and Management 26(4): 467-85.

2. Ahammad, Mohammad Faisal, Keith W. Glaister, Riikka M. Sarala, and Alison J. Glaister. 2018. "Strategic Talent Management in Emerging Markets." Thunderbird International Business Review 60(1): 5-8.

3. Ahammad, Mohammad Faisal, Keith W. Glaister, Yaakov Weber, and Shlomo Yedidia Tarba. 2012. "Top Management Retention in Cross-Border Acquisitions: The Roles of Financial Incentives, Acquirer's Commitment and Autonomy." European J. of International Management 6(4): 458-80.

4. Alaraqi, Ali Kadhim. 2017. "Relationship between SHRM and Organizational Performance among Iraqi Oil Companies." Journal of Global Economics 5(1): 1-12.

5. Aldamoe, Fathi Mohamed Abduljlil, Mohamd Yazam, and Kamal Bin Ahmid. 2011. "The Mediating Effect of HRM Outcomes (Employee Retention) on the Relationship between HRM Practices and Organizational Performance.' International Journal of Human Resource Studies 2(1): 75-88.

6. Ali, Asiah, Abd Rahim Zumrah, and Lokman Hakim Abu Samah. 2017. "Employee Retention as a Mediator of the Relationship between Peer Support and Organizational Citizenship Behavior." Australian Journal of Basic and Applied Sciences 11(August): 71-78. 
7. Alias, Nurul Ezaili, Norzanah Mohd Noor, and Roshidi Hassan. 2014. "Examining the Mediating Effect of Employee Engagement on the Relationship between Talent Management Practices and Employee Retention in the Information and Tec .... Examining the Mediating Effect of Employee Engagement on the Relationship between Talent M." Journal of Human Resources Management and Labor Studies 2(2): 227-42.

8. Alkhalaf, A. H., A. Zaballero, and R. A. Alzahmi. 2015. "Talent Pipeline Management: Attracting, Developing, and Retaining Talents to Meet Future Drilling Challenges." In Abu Dhabi International Petroleum Exhibition and Conference, Abu Dhabi: Society of Petroleum Engineers, 110.

9. Alzaabi, Ahmed. 2012. "The Risks That Foreign Labor Poses to UAE National Security." Fort Leavenworth, Kansas.

10. Antonsen, Stian, Kari Skarholt, and Arne Jarl Ringstad. 2012. "The Role of Standardization in Safety Management - A Case Study of a Major Oil \& Gas Company." Safety Science 50(10): 2001-9.

11. Ashraf, G. 2017. "A Review of the Role of Talent Management on the Partnership Motivation of Employees.' Journal of Administrative Management, Education and Training 13(2): 292-300.

12. Awan, Abdul Ghafoor, and Hafiz Muhammad Farhan. 2016. "Talent Management Practices and Their Impact on Job Satisfaction of Employees : A Case Study of Banking Sector In." Science International 28(2): 1949-55.

13. Bartlomiejczuk, Greg, and Sanghoon Jin. 2015. "What Are the Relationships Between Job and Organizational Tenure, and Job Performance?" Cornell University.

14. Beamond, Maria Teresa, Elaine Farndale, and Charmine E.J. Härtel. 2016. "MNE Translation of Corporate Talent Management Strategies to Subsidiaries in Emerging Economies.” Journal of World Business 51(4): 499-510.

15. Cappelli, Peter, and JR Keller. 2014. "Talent Management: Conceptual Approaches and Practical Challenges." The Annual Review of Organizational Psychology and Organizational Behavior 1(1): 305-31.

16. Chiboiwa, Malvern W., Michael O. Samuel, and Crispen Chipunza. 2010. "An Examination of Employee Retention Strategy in a Private Organisation in Zimbabwe." African Journal of Business Management 4(10): 2103-9.

17. Collings, David G., Hugh Scullion, and Vlad Vaiman. 2015. "Talent Management: Progress and Prospects." Human Resource Management Review 25(3): 233-35.

18. Cooke, Fang Lee, Debi S. Saini, and Jue Wang. 2014. "Talent Management in China and India: A Comparison of Management Perceptions and Human Resource Practices." Journal of World Business 49(2): 225-35.

19. Corner, Judy. 2014. "The Fast Are Eating the Slow: Mentoring for Leadership Development as a Competitive Method." Industrial and Commercial Training 46(1): 29-33.

20. Cui, Wenjia, Zaheer Khan, and Shlomo Y. Tarba. 2016. "Strategic Talent Management in Service SMEs of China." Thunderbird International Business Review 60(1): 9-20.

21. Deery, Margaret, and Leo Jago. 2015. "Revisiting Talent Management, Work-Life Balance and Retention Strategies." International Journal of Contemporary Hospitality Management 27(3): 453-72.

22. Dhanpat, Nelesh et al. 2019. "Exploring Retention Factors and Job Security of Nurses in Gauteng Public Hospitals in South Africa." African Journal of Economic and Management Studies 10(1): 57-71.

23. Dias, Diana, Ângela Leite, Ana Ramires, and Paula Bicho. 2017. "Working with Cancer: Motivation and Job Satisfaction." International Journal of Organizational Analysis 25(4): 662-86.

24. Díaz-Fernández, Mirta, Alvaro López-Cabrales, and Ramón Valle-Cabrera. 2014. "A Contingent Approach to the Role of Human Capital and Competencies on Firm Strategy.” BRQ Business Research Quarterly 17(3): 205-22.
25. Dixit, Shailly, and Mini Amit Arrawatia. 2018. "The Impact of Talent Management on Job Satisfaction and Employee Performance in Public Sector Banks of Rajasthan.' International Journal of Creative Research Thoughts (IJCRT) 6(1): 425-35.

26. Dutta, Debolina. 2014. "Tweet Your Tune - Social Media, the New Pied Piper in Talent Acquisition." Vikalpa 39(3): 93 104.

27. Embassy of The United Arab Emirated. 2019. "The UAE and Global Oil Supply | UAE Embassy in Washington, DC."

28. Ewers, Michael C. 2016. "Oil, Human Capital and Diversification: The Challenge of Transition in the UAE and the Arab Gulf States." The Geographical Journal 182(3): 23650.

29. Fathaniy, Ahmad Zackiy. 2011. "The Role of HR Practices, Supervisory Support and Work-Life Balance Policies on Employee Intention to Stay: A Study in Oil and Gas Company." Universiti Utara Malaysia.

30. Foster, Helen, Ann Ooms, and Di Marks-Maran. 2015. 'Nursing Students' Expectations and Experiences of Mentorship." Nurse Education Today 35(1): 18-24.

31. Froese, Fabian Jintae. 2012. "Motivation and Adjustment of Self-Initiated Expatriates: The Case of Expatriate Academics in South Korea." The International Journal of Human Resource Management 23(6): 1095-1112.

32. Gallardo-Gallardo, Eva, and Marian Thunnissen. 2016. "Standing on the Shoulders of Giants? A Critical Review of Empirical Talent Management Research.” Employee Relations 38(1): 31-56.

33. Gberevbie, Daniel Eseme. 2010. "Organizational Retention Strategies and Employee Performance of Zenith Bank in Nigeria." African Journal of Economic and Management Studies 1(1): 61-74.

34. Gelens, Jolyn, Joeri Hofmans, Nicky Dries, and Roland Pepermans. 2014. "Talent Management and Organisational Justice: Employee Reactions to High Potential Identification.' Human Resource Management Journal 24(2): 159-75.

35. Gopal, R., and Rima Ghose Chowdhury. 2014. "Leadership Styles and Employee Motivation: An Empirical Investigation in a Leading Oil Company in India." International Journal of Research in Business Management 2(5): 1-10.

36. Hannawi, Suad, and Issa Al Salmi. 2014. "Health Workforce in the United Arab Emirates: Analytic Point of View." International Journal of Health Planning and Management 29(4): 332-41.

37. Harhara, Afif Saif, Sanjay Kumar Singh, and Matloub Hussain. 2015. "Correlates of Employee Turnover Intentions in Oil and Gas Industry in the UAE." International Journal of Organizational Analysis 23(3): 493-504.

38. Hitu, and Satyawan Baroda. 2016. "Impact of Talent Management Practices on Employees' Performance in Private Sector Bank." International Journal of Management (IJM 9(1): 16-21.

39. Idris, Aida. 2012. "Flexible Working as an Employee Retention Strategy in Developing Countries: Malaysian Bank Managers Speak." Journal of Management Research 14(2) 71-86.

40. James, Julie M., Ashley Rayner, and Jeannette Bruno. 2015. "Are You My Mentor? New Perspectives and Research on Informal Mentorship." Journal of Academic Librarianship 41(5): 532-39.

41. Jefri, Nurul Aqilah Mohd, and Normala Daud. 2016. "Exploring Employee Retention among Gen Y in Oil and Gas Industry in Malaysia." International Academic Research Journal of Business and Technology 2(2): 152-56. 
42. Khilji, Shaista E., Ibraiz Tarique, and Randall S. Schuler. 2015. "Incorporating the Macro View in Global Talent Management." Human Resource Management Review 25(3): 236-48.

43. Kontoghiorghes, Constantine. 2015. "Linking High Performance Organizational Culture and Talent Management: Satisfaction/Motivation and Organizational Commitment as Mediators." International Journal of Human Resource Management 27(16): 1833-53.

44. Kumari, P, and P Bahuguna. 2012. "Measuring the Impact of Talent Management on Employee Behaviour: An Empirical Study of Oil and Gas Industry in India." Journal of Human Resource Management 2(2): 65-85.

45. Lacey, Miriam Y., and Kevin Groves. 2014. "Talent Management Collides with Corporate Social Responsibility: Creation of Inadvertent Hypocrisy." Journal of Management Development 33(4): 399-409.

46. Lyria, Rita Kagwiria, G.S Namusonge, and Kabare Karanja. 2014. "Effect of Talent Retention on Organisation Performance in Companies Listed in Nairobi Securities Exchange in Kenya." European Journal of Business and Social Sciences 3(1): 47-58.

47. Lyria, RK, GS Namusonge, and Kabare Karanja. 2017. "The Effect of Talent Attraction on Organizational Performance of Firms Listed in the Nairobi Securities Exchange." Journal of Human Resource and Leadership 1(3): 18-30.

48. Mahjoub, Mahdiyeh et al. 2018. "Linking 'Project Success' and 'Strategic Talent Management': Satisfaction/Motivation and Organizational Commitment as Mediators." In Procedia Computer Science, Elsevier B.V., 764-74.

49. Mangusho, Yona Sakaja, Raphael Kipkoech Murei, and Eunice Nelima. 2015. "Evaluation of Talent Management on Employees Performance in Beverage Industry: A Case of Del Monte Kenya Limited." International Journal of Humanities and Social Science 5(8): 191-99.

50. Marimuthu.M, Arokiasamy.L, Ismail, M. 2009. "Human Capital Development and Its Impact on Firm Performance: Evidence from Developmental Economics." Journal of International Social Research 2(8): 265-72.

51. Meyers, M. Christina, Marianne van Woerkom, and Nicky Dries. 2013. "Talent - Innate or Acquired? Theoretical Considerations and Their Implications for Talent Management." Human Resource Management Review 23(4): 305-21.

52. Meyers, Maria Christina, and Marianne van Woerkom. 2014. "The Influence of Underlying Philosophies on Talent Management: Theory, Implications for Practice, and Research Agenda.” Journal of World Business 49(2): 192-203.

53. Montgomery, Eddie G, and Victor Oladapo. 2014. "Talent Management Vulnerability in Global Healthcare Value Chains : A General Systems." Journal of Business Studies Quarterly 5(4): 173-90.

54. Mwanzi, Jane, Susan Wamitu, and Michael Kiama. 2017. "Influence of Talent Management on Organizational Growth." IOSR Journal of Business and Management 19(8): 1-36.

55. Naulleau, Mickael. 2018. "When TM Strategy Is Not SelfEvident: Action Research with a Mid-Sized French Company on Organizational Issues Affecting TM Strategy." Management Decision 57(5): 1204-22.

56. Nwoye, Chizoba C. 2017. "Retaining Employees After Downsizing." Walden University.

57. Osaro, Comfort. 2016. "Talent Attraction and Employee Retention in Oil Firms in Rivers State." International Journal of Novel Research in Humanity and Social Sciences 3(2): 7584.

58. Osibanjo, A.O., A.A. Adeniji, H.O. Falola, and P.T. Heirsmac. 2014. "Compensation Packages: A Strategic Tool for Employees' Performance and Retention." Leonardo Journal of Sciences 25: 65-84.
59. Pang, Kelvin, and Chin-Shan Lu. 2018. "Organizational Motivation, Employee Job Satisfaction and Organizational Performance.” Maritime Business Review 3(1): 36-52.

60. Parker, Sharon K. 2014. "Beyond Motivation: Job and Work Design for Development, Health, Ambidexterity, and More.' The Annual Review of Psychology 65: 661-91.

61. Pegram, J, G Falcone, A Kolios - Energies, and Undefined 2018. 2018. "A Review of Job Role Localization in the Oil and Gas Industry." Energies 11(10): 1-18.

62. Pobst, Gloria Ferguson. 2014. "Meeting the Challenge of Knowledge Worker Shortages with Strategic Talent Management." American Journal of Management 14(1/2): 6266.

63. Rabbi, Faria. 2015. "Talent Managment as a Source of Competitive Advantage." Journal of Asian Business Strategy journal 5(9): 208-14.

64. Rashid, N., N. F. Alzahrani, and A Al-shami. S. 2018. "THE RELATIONSHIP BETWEEN TRAINING DEVELOPMENT PROCESS AND TRAINING DEVELOPMENT PROCESS AND EMPLOYEES'." Journal of Fundemental and Applied Science 10(6s): 2616-33.

65. Richardson, Christopher, and Hsin Wei Wong. 2018 "Expatriate Academics in Malaysia: Motivation, Adjustment, and Retention." Journal of Management Development 37(3) 299-308.

66. Robescu, Ofelia, and Alina-Georgiana Iancu. 2016. "The Effects of Motivation on Employees Performance in Organizations." Valahian Journal of Economic Studies 7(21) 49-56.

67. Rudhumbu, Norman, and Cosmas Maphosa. 2017 "Implementation of Talent Management Strategies in Higher Education: Evidence from Botswana." Journal of Human Ecology 49(1-2): 21-32.

68. Rutledge, Lorelei, Sarah LeMire, Melanie Hawks, and Alfred Mowdood. 2016. "Competency-Based Talent Management: Three Perspectives in an Academic Library." Journal of Library Administration 56(3): 235-50.

69. Sahay, Pradeep. 2014. "Design Thinking in Talent Acquisition: A Practitioner's Perspective." Strategic HR Review 13(4/5): 170-80.

70. Sarmad, Muhammad et al. 2016. "Motivation and Compensation as Predictors of Employees' Retention: Evidence From Public Sector Oil and Gas Selling Organizations.” Journal of Behavioural Sciences 26(2): 17488.

71. Schreuder, Rino, and Simon Noorman. 2019. "Strategic Talent Management: Creating Strategic Value by Placing Top Talents in Key Positions." International Journal of Organizational Analysis 33(1): 185-99.

72. Schuler, Randall, and Ibraiz Tarique. 2012. "International Joint Venture System Complexity and Human Resource Management." In Handbook of Research in International Human Resource, eds. Günter K. Stahl and Ingmar Björkman. Cheltenham, UK: Edward Elgar Publishing Limited, 385.

73. Shamsi, Saeed Ali Obaid Al, Christopher Dixon, Chowdhury Golam Hossan, and Marina Papanastassiou. 2015. "Coaching Constructs and Leadership Development at an Oil and Gas Company in the United Arab Emirates." Journal of Competitiveness Studies 23(1/2): 13-33.

74. Sharma, Rakesh, and Jyotsna Bhatnagar. 2009. "Talent Management - Competency Development: Key to Global Leadership.” Industrial and Commercial Training 41(3): 11832.

75. Shortland, Susan. 2018. "Female Expatriates' Motivations and Challenges: The Case of Oil and Gas Article Information.' Gender in Management: An International Journal 33(1): 5065. 
76. Skuza, Agnieszka, Hugh Scullion, and Anthony McDonnell. 2013. "An Analysis of the Talent Management Challenges in a Post-Communist Country: The Case of Poland." International Journal of Human Resource Management 24(3): 453-70.

77. Smith, Andrew, Edward Oczkowski, and Chris Selby Smith. 2011. "To Have and to Hold: Modelling the Drivers of Employee Turnover and Skill Retention in Australian Organisations." International Journal of Human Resource Management 22(2): 395-416.

78. Subramaniam, Anusuiya, Abu Daud Silong, Jegak Uli, and Ismi Arif Ismail. 2015. "Effects of Coaching Supervision, Mentoring Supervision and Abusive Supervision on Talent Development among Trainee Doctors in Public Hospitals: Moderating Role of Clinical Learning Environment." BMC Medical Education 15(1): 1-9.

79. Sumbal, Muhammad Saleem, Eric Tsui, Ricky Cheong, and Eric W.K. See-to. 2018. "Critical Areas of Knowledge Loss When Employees Leave in the Oil and Gas Industry." Journal of Knowledge Management 22(7): 1573-90.

80. Tabatabaei, Seyyed Akbar Nilipour, and Malek Mami. 2015. "Investigating the Role of Talent Management System (TMS) in the Human Resources Management." International Journal of Human Resource Studies 5(4): 36-49.

81. Tafti, Marjan Maali, Mahdi Mahmoudsalehi, and Mojtaba Amiri. 2017. "Critical Success Factors, Challenges and Obstacles in Talent Management." Industrial and Commercial Training 49(1): 15-21.

82. The International Trade Administration. 2018. "United Arab Emirates - Oil and Gas Field Machinery and Services."

83. Thunnissen, Marian. 2016. "Talent Management: For What, How and How Well? An Empirical Exploration of Talent Management in Practice.” Employee Relations 38(1): 57-72.

84. Thunnissen, Marian, Paul Boselie, and Ben Fruytier. 2013. "A Review of Talent Management: 'Infancy or Adolescence?", The International Journal of Human Resource Management 24(9): 1744-61.

85. Tripathi, Kaushiki, and Manisha Agrawal. 2014. "Tripathi, K. and Agrawal, M., 2014. Competency Based Management in Organizational. Global Journal of Finance and Management, 6(4), Pp.349-356." Global Journal of Finance and Management 6(4): 349-56.

86. Ugwu, Kelechi Enyinna, and Halida E Osisioma. 2017. "Talent Management and Performance of Selected Commercial Banks in Owerri, Imo State, Nigeria." International Journal of Management, Accounting and Economics 4(3): 282-310.

87. Vinodkumar, M. N., and M. Bhasi. 2010. "Safety Management Practices and Safety Behaviour: Assessing the Mediating Role of Safety Knowledge and Motivation." Accident Analysis and Prevention 42(6): 2082-93.

88. Vnoučková, Lucie. 2016. "Practices of Talent Management in Organisations in the Czech Republic." Acta Universitatis Agriculturae et Silviculturae Mendelianae Brunensis 64(2): 701-9.

89. Wu, Wei, and Raja R.A. Issa. 2014. "Key Issues in Workforce Planning and Adaptation Strategies for BIM Implementation in Construction Industry." In Construction Research Congress, , 847-56.

90. Zhang, Jiali et al. 2015. "The Effect of Leadership Style on Talent Retention during Merger and Acquisition Integration: Evidence from China." International Journal of Human Resource Management 26(7): 1021-50. 